\title{
"Careful, Now You Are both the Learner and the Teacher!": Student Teachers' Evaluation of Inquiry-Based Peer Lecturing as a Tool in Teacher Training
}

\author{
Dominique-Esther Seroussi ${ }^{1,2}$, Yossi Yaffe ${ }^{3,4} \&$ Rakefet Sharon ${ }^{1,5}$ \\ ${ }^{1}$ Department of Science Teaching, Ohalo Academic College, Katsrin, Israel \\ ${ }^{2}$ Department of Medical Laboratory Science, Safed Academic College, Safed, Israel \\ ${ }^{3}$ School of Education, Ohalo Academic College, Katzrin, Israel \\ ${ }^{4}$ Tel Hai Academic College, Kyriat Shemona, Israel \\ ${ }^{5}$ Northern Research \& Development, Kiryat Shemona, Israel \\ Correspondence: Dominique-Esther Seroussi, Department of Science Teaching, Ohalo Academic College, PO \\ Box 222, Katsrin 12900, Israel. Tel: 972-54-802-5155. E-mail: domestherseroussi@gmail.com
}

Received: January 12, 2017

Accepted: February 15, 2017

Online Published: May 29, 2017

doi:10.5539/ies.v10n6p100

URL: https://doi.org/10.5539/ies.v10n6p100

\begin{abstract}
Linking between pedagogical content knowledge and high-level subject-matter knowledge in science teacher training remains a challenge. This paper analyses the reaction of beginning student teachers to an activity designed for this purpose, peer lecturing. This activity was a part of the requirements of an introductory zoology course, and included students' literature inquiry processes oriented to answer a question linked to the course's contents, followed by whole class presentation of the knowledge acquired in the inquiry. According to students' view, it seems that the inquiry component and the peer learning component of the activity induced original characteristics in the activity concerning student teachers' self-concept, students' beliefs about the level of knowledge needed to teach science, their treatment of prior conceptions, and multiple sources of reflective thinking on science teaching. On the basis of these results, the further development of teacher training activities is envisioned.
\end{abstract}

Keywords: teacher training, subject-matter knowledge, pedagogical content knowledge, reflection

\section{Introduction}

\subsection{The Centrality of SMK in Teachers' PCK Development}

Beside disciplinary knowledge (knowledge in the subject matter which the teacher is teaching), and general pedagogical knowledge, the concept of pedagogical content knowledge (PCK) was introduced by Lee Shulman (1987, p. 15) to express "the capacity of a teacher to transform the content knowledge he or she possesses into forms that are pedagogically powerful and yet adaptive to the variations in ability and background presented by students." In scientific disciplines, PCK can be broken down into the following components (Magnusson, Krajcik \& Borko, 1999): (a) orientations toward science teaching, (b) knowledge and beliefs about science curriculum, (c) knowledge and beliefs about students' understanding of specific science topics, (d) knowledge and beliefs about assessment in science, and (e) knowledge and beliefs about instructional strategies for teaching science.

According to all authors dealing with PCK formation, teachers' learning in the subject matter they teach is fundamental not only as a source of subject matter knowledge (SMK), but also as a source of pedagogical knowledge (Kind, 2009). The first reason for this importance can be found in the definition of the teaching profession as a profession dealing with people's behaviour and not with objects, such that contains the possibility for the professional to verify on herself the application of the principles of her profession. Therefore, adequate preparation for teaching requires from the teacher not only learning how to help others to learn, but also learning how to learn, that is, developing as a "professional learner" (Parker \& Heywood, 2013). This implies the necessity for teachers to acquire strong learning strategies (Hwang \& Vrongistinos, 2002), to develop an understanding of the learning process allowing them to link it to the teaching process (Vermunt \& Verloop, 1999), 
and to stay constantly engaged in continuous learning in the subject-matter they teach or in learning new topics in order to teach them (Feiman-Nemser, 2001), that is, in "learning for teaching" (Shulman, 1986). The second reason for the importance of teachers' disciplinary learning in PCK development, is to be found in the nature of pedagogical content knowledge. For Shulman and his colleagues (Wilson, Shulman, \& Richert, 1988), PCK is not the sum of subject-matter knowledge (SMK) and of general pedagogical knowledge, but an original form of knowledge which teachers develop by transforming their SMK and other types of knowledge (Loughran, Mulhall, \& Berry, 2008; Magnusson et al., 1999). The idea of PCK developing from SMK has at least three consequences in what concerns the link between PCK and SMK in teacher training. First, it means that it is impossible to instil disciplinary pedagogical skills to prospective teachers without grounding them on disciplinary knowledge (Ball, Thames \& Phelps, 2008; Capraro, Capraro, Parker, Kulm \& Raulerson, 2005; Friedrichsen et al., 2009). Conversely, it implies that it is not logical to expect disciplinary pedagogical skills to bloom automatically in prospective teachers from the mere study of the discipline they have to teach (Mellado, 1998). Third, it suggests, in a fully constructivist perspective, that teacher training should not only instil theories and strategies of disciplinary teaching, but also serve as a mediator in student teachers' personal process of acquiring PCK, that is, help student teachers develop self-regulation in learning to teach (Ball \& Cohen, 1999; Randi, 2004). The active role of teachers in developing their teaching skills in general, is developed in a model of learning to teach based on the concept of self-regulated learning (Corno \& Randi, 1999; Kramarski \& Kohen, 2015), where self-regulation in learning (SRL) is defined in general as the active and conscious effort of learners to manage their motivation, cognitive and metacognitive activity, and behaviour when learning (Zimmerman, 2008). This model of self-regulation in learning to teach gives a theoretical basis to the focus on reflective thinking in teaching to teach (Lackner-Saylor \& Johnson, 2014; Schön, 1987; Zeichner, 1996).

In summary, disciplinary studies are the basis of multiple aspects of teacher development: learning the discipline, learning how to learn in the discipline, learning to understand the learning process in the discipline, and building a basis for disciplinary teaching skills, that is, PCK.

\subsection{Teacher Training Programs Helping Preservice Teachers to Build PCK on SMK}

The recommendations provided for teacher training by different authors highlight the importance of disciplinary studies in teachers' PCK development. The study of subject-matter knowledge appears, for instance, in all the steps proposed by Magnusson, Krajcik and Borko (1999) for effectively helping preservice teachers to develop PCK:

"1. Helping teachers examine their pre-existing ideas and beliefs

2. Addressing the relationship between subject matter knowledge and PCK

3. Situating learning experiences for teachers in meaningful contexts

4. Using a model of components of PCK to guide learning-to-teach experiences"

Similarly, in Desimone's (2009) "core conceptual framework for professional development", "content focus" is a central preoccupation.

In practice, the way in which subject matter instruction is involved in initial training remains a concern for professionals in this field. After Shulman's (1986) seminal call for a more significant inclusion of subject matter knowledge in teacher training programs, the next generation of researchers in the science teaching field expressed a concern about the abundance of training programs which do reinforce disciplinary knowledge, but without transforming it into pedagogical content knowledge (Poulson, 2001). Up to the present, efforts for adequately relating SMK and PCK are the core of a variety of teacher training programs which offer the students many possibilities to develop self-regulation in learning to teach and in teaching (Evens, Elen, \& Depaepe, 2015).

The most sophisticated programs of this kind belong to the category of "integrated curricula", and are curricula which concurrently teach new scientific contents and pedagogic knowledge in the same discipline, while the students teach related contents in the field application schools and finally lead a reflection on their experience (Rubba, Campbell, \& Dana, 1993). One example is the program presented by Briscoe, Peters and O'Brien (1993), including a general science course whose contents are related to the contents experienced in field application schools, guided reflection on science and on inquiry, and inquiry learning followed by peer teaching sessions of topics which the students chose by themselves (see also Justi \& van Driel, 2005). Similarly, Sperandeo-Mineo, Fazio and Tarantino (2006) report a teacher training program centred on several topics of secondary physics where the pre-service students were offered the following steps: they studied pupils' misconceptions and reflected about their possible sources, conducted a short experimental scientific inquiry on the same topic, 
applied mathematical modelling tools to their experimental results, reflected on the way they learned, and finally built learning units at school level in the field of the activities they experienced.

Integrated curricula are not always practicable, since that would imply the investment of a large amount of time and means into a small amount of subject matter, and require a careful adaptation of courses' schedules and contents in the institution (Magnusson et al., 1999). Simpler programs combining SMK learning and PCK development in one single course are also reported. For instance, Luft et al. (2011) describe a science-induction program where in-service beginning teachers were mentored by science and science education researchers in addition to experienced teachers. Mamlok-Naaman, Blonder, and Hofstein (2010) propose a program involving in-service teachers in graduate science courses followed by special tutoring and application to teaching. Michalsky (2012) reports a science methods workshop where pre-service teachers are induced to solve science problems, reflect on their learning process, try to predict pupils' difficulties, and analyse movies showing teachers teaching similar topics. Similarly, Parker and Heywood (2013) include in a science methods course learning sessions of new physics contents, reflection on learning, discussion on the way to introduce the same contents to pupils, and finally critical consideration of elementary school programs.

Such courses linking SMK and PCK also include inquiry learning as an authentic experience in the learning settings which the students should be applying as teachers (Crawford, 2007). Britner and Finson (2005), for instance, describe how preservice teachers plan and conduct a scientific experimental inquiry on a "topic of personal interest" and subsequently prepare and enact an inquiry-based lesson at elementary school level (see also Magee \& Flessner, 2012). Friedrichsen, Munford, and Zembal-Saul (2003) engaged preservice teachers in scientific literature-based problem-based learning which was followed by communications where the students introduced the results of their inquiry to their peers. These studies present self-reported gains in students' ability and motivation to teach, and show also the depth of the reflection which the activities induced.

\subsection{Peer Lecturing as a Tool in Preservice Science Teachers' PCK Acquisition}

Because of the difficulties student teachers have in translating their experience as learners into teaching strategies (see for instance, Chamoso, Cáceres, \& Azcárate, 2012), we wanted to ground PCK building in a situation of high level SMK and authentic disciplinary learning (Parker \& Heywood, 2013; Shulman, 1986), and therefore we chose to override the limits of the methods courses and to allow the students to experience a pedagogical process within a disciplinary course itself. At the same time, we set for ourselves the constraint to respect the primary scope and organisation of the course as a fully disciplinary course. In this state of mind, we included in the requirements of a first-year introductory zoology course in teachers college, an activity which we called peer lecturing (Seroussi \& Sharon, 2017). In this activity, the students had to search in their own time academic-level information intended to answer a question which they chose by themselves and which had to be linked to the scope of the course, and had to teach the result of their search to their peers at college level in the form of a professional scientific communication in the framework of the course's lessons, with the aim of helping the peers understand the topic of the lecture as well as possible.

\subsection{Purpose and Research Questions}

The general goal of the investigations reported in this paper was to check whether and how peer lecturing helps preservice teachers in their pedagogical development.

As a tool in disciplinary teaching, like we already showed (Seroussi \& Sharon, 2017), peer lecturing is a form of project-based learning in which the social context adds original sources of motivation to learn, original cognitive scaffolds, and multiple contexts for reflecting about the learning process. For preservice teachers, this means profitable gains in disciplinary knowledge, as well as in knowledge about learning process (Seroussi \& Sharon, 2017).

As a teacher training tool, peer lecturing instils in a regular peer-teaching exercise the components of high-level disciplinary knowledge, of inquiry, and of peer learning (Seroussi \& Sharon, 2017). Therefore, as summarised in Table 1, it seemed very appropriate to most requirements established for the development of PCK in preservice teachers (Magnusson et al., 1999) and to some of the guidelines given for their SRL development (Corno \& Randi, 1999). 
Table 1. Characteristics of peer lecturing as they relate to requirements for activities designed to develop PCK and SRL in student teachers according to a constructivist view of teacher training. The symbols * and \# refer to the two different sources: * (Magnusson et al., 1999), \# (Corno \& Randi, 1999)

\begin{tabular}{|c|c|}
\hline $\begin{array}{l}\text { Requirements for teacher } \\
\text { training activities } \\
\text { designed to develop PCK }\end{array}$ & Characteristics of peer lecturing and research hypotheses \\
\hline $\begin{array}{l}\text { "Allowing the students to } \\
\text { actively develop their } \\
\text { PCK" \# }\end{array}$ & $\begin{array}{l}\text { The task matches the situation in which teachers find themselves when preparing their lessons, regarding the } \\
\text { degree of autonomy in learning, and the demands of self-regulation imposed upon them (Kramarski \& } \\
\text { Michalsky, 2009). }\end{array}$ \\
\hline $\begin{array}{l}\text { "Encourage teachers to } \\
\text { invent, rather than imitate } \\
\text { instructional practices" } \\
\text { "Afford teachers choices } \\
\text { about instruction" } \\
\text { "Places students at the } \\
\text { center of teacher } \\
\text { learning"\# }\end{array}$ & $\begin{array}{l}\text { According to the principle of discovery learning, it seemed to us that before preservice teachers are taught a } \\
\text { deeper knowledge in science education, they could benefit from an early, student-centred, and rather } \\
\text { non-directive experience in teaching, that is, from some "discovery teaching" (Feiman-Nemser, 1983). In order } \\
\text { to grant the students relative freedom in their PCK development during this first experience, only a small } \\
\text { number of constraints (time limit and college level) were set concerning the way the student teachers had to } \\
\text { teach their lesson. We expected the activity to rise students' awareness of the need to develop PCK in science } \\
\text { teaching. }\end{array}$ \\
\hline $\begin{array}{l}\text { "Situating learning } \\
\text { experiences for teachers } \\
\text { in meaningful contexts"* }\end{array}$ & $\begin{array}{l}\text { The format of the activity as project-based learning allowed the students to experience by themselves as } \\
\text { learners one of the teaching methods they will use as teachers in schools (Crawford, 2007; Michalsky, 2012). } \\
\text { The inclusion of the activity as a requirement in a disciplinary course ensured that the students involved } \\
\text { themselves in learning with a sustained effort. }\end{array}$ \\
\hline $\begin{array}{l}\text { "Helping teachers } \\
\text { examine their pre-existing } \\
\text { ideas and beliefs" * }\end{array}$ & $\begin{array}{l}\text { The necessity of discovering and studying by themselves the topic they have to teach, was expected to enhance } \\
\text { student teachers' sensitivity to their prior conceptions on the topic (Parker \& Heywood, 2013) }\end{array}$ \\
\hline $\begin{array}{l}\text { "Addressing the } \\
\text { relationship between } \\
\text { subject matter knowledge } \\
\text { and PCK"* }\end{array}$ & $\begin{array}{l}\text { The inclusion of students' first experience in science teaching in a disciplinary course instead of a science } \\
\text { teaching methods course was expected to make students aware of the centrality of disciplinary learning in PCK } \\
\text { development and of the necessity to develop PCK in order to teach science at any level. } \\
\text { The requirement of discovering and studying by themselves the topic they had to teach was intended to allow } \\
\text { the student teachers to link between the learning and teaching processes. }\end{array}$ \\
\hline
\end{tabular}

Our research questions were:

What did the students feel they gained from peer lecturing concerning teacher training?

How did the students think that peer lecturing generated these gains?

Because the characteristics of peer lecturing fit well the requirements for PCK developing activities (Table 1), our hypotheses were that the activity should (a) strengthen students' awareness of the centrality of disciplinary learning in PCK development, (b) rise students' awareness of the need to develop PCK in science teaching, (c) help the students to assimilate inquiry-learning as a teaching strategy, (d) enhance students' sensitivity to their prior conceptions on the topic they teach, and (e) prompt the students to link between the learning and teaching processes.

In accordance with the constructivist conception of PCK which we presented here, we examined our research questions within the theoretical framework of the self-regulated learning model, which breaks down students' monitoring of their learning process into three dimensions: affective, cognitive, and regulative (Pintrich, 2004). Because the student teachers were still lacking theoretical literacy in science teaching, a more sophisticated framework for PCK analysis was not adapted. We chose to use the tools of qualitative research, because we expected to encounter unpredicted parameters. Data collection was mostly based on students' self-report, since students' perception of the activity in which they learn influences the success of the activity (Entwistle, 1991), and since, when the students are preservice teachers, it influences the ability of the students to assimilate the pedagogical principles of the activity and their readiness to use it in their future activity as teachers (Crawford, 2007).

\section{Method}

Additional details about the participants in the research, the activity, the interview procedure, and the way the data were analysed, are found in a previous report (Seroussi \& Sharon, 2017). 


\subsection{Participants}

The participants in the activity were first-year preservice teachers specializing in science teaching (at elementary or junior high school level, with no strict distinction between them at this stage) at a small teachers' college in northern Israel: 21 females and 2 males, 17 from Hebrew speaking and 6 from Arabic speaking high schools. These students learned a year-long introductory zoology course and in parallel, they participated, together with other non-science students, to a year-long general teaching method workshop (6 weekly hours), during which they began to train in microteaching sessions in the second semester, independently from our activity.

\subsection{Format of the Activity}

Peer lecturing took place after one semester of participative professor's lectures in zoology. During the first three weeks of the second semester, each student (or pair of students if they wished) was asked to choose a topic linked to one of the chapters remaining to be taught and to define a research question linked to this topic. Students' inquiries were done outside the course and they had to report their choice to the lecturer. Example of questions were "What are the causes and expression of albinism in animals?", "What is Jacobson organ in snakes and how does it function?". After receiving the permission to start, each student begun (outside the course) to search for academic information on her topic, and to build a ten-minute presentation for the class. One week before their lesson, the students had to publish a one-page summary of their lecture in the course's forum. This last assignment served as a scaffold which obliged the students to focus on a limited topic and to clearly formulate their findings. During the whole process, the students were free to ask the professor for help by e-mail or during talks before the lectures; did used this possibility without exageration, and the issues about which they mostly sought help were the choice of the lecture's topic, information sources and seeking strategies, the explanation of some complex scientific aspects, and sometimes the scientific format of the summary (particularly the order of the different topics).

\subsection{Data Collection}

Several days, after she gave her lecture (and not after the final examination), each student participated a 30-minute semi-structured interview with the first author. Before the interview, the student was instructed to tell about each part of the activity (information search, presentation building, lecture), what she did, what she liked in this part, what was difficult, and what she learned. 4 months after the examination, several short talks were made with some students. The interviews' and talks' scripts, along with students' summaries of the lectures, presentation files, written comments in the courses' forum, and final examination forms served as data for this report.

\section{Results}

In the interviews, half of students' speaking time focused on their own learning process (information search, definition of a research question, data understanding). The other half bore on teaching aspects and on students' evaluation of the activity. As previously reported (Seroussi \& Sharon, 2017), the transcripts of the interviews underwent a content analysis according to the principle of the grounded theory methodology (Charmaz, 2006), and this process yielded 43 categories pertaining to learning (dealing with subject choice, information search and processing, conception of science) and 22 categories pertaining to learning to teach. The latter categories were clustered again according to the three dimensions of SRL and to the different aspects of PCK as summarized hereunder.

Students' reactions to the activity differed according to students' initial academic level, and therefore, in the results, we grouped the students into three groups accordingly in our analysis of peer lecturing: "A ( 9 students with grades over 85), B (10 students with grades between 70 and 84) and C (4 students with grades below 70). Students' talk showed that A students expressed both high competitiveness and high level of interest in the activity, B students rather displayed a willingness to do a good job and to enjoy the activity, and C students expressed interest in the activity but did not report as strong an effort as the others.

As will be seen, students' discourse matches the results reported by Britner and Finson (2005) in their study of an experimental inquiry activity for preservice teachers: for instance, an increased motivation to teach science, a readiness to use the activity as a model for future teaching, and a more sophisticated concern for future pupils' coping with inquiry.

\subsection{Affective Gains in Teacher Training}

Like every teaching exercise, peer lecturing was reported by all the students as fostering the development of their self-concept as a teacher and of their feeling of self-efficacy (Bandura, 1986), due to the success in managing the audience or in answering questions during or after the lecture. 
Additional affective gains were related to the originality in the subjects of the lessons brought by the inquiry dimension of the activity:

"At the beginning I was afraid. But when I saw the [look of surprise on the] faces of the students, my self-confidence got a real boost!" (Jasmine, C).

The possibility to choose the topic of one's lecture yielded an enhanced motivation for teaching in all the students, as Maria (B) explained:

"The most important thing is that the topic of your lecture interests you, because if not, you won't introduce it in an attractive way."

According to the students, the inquiry aspect of the activity added in peer lecturing sources of motivation to teach which were not present in the lessons they gave in their general methods workshop:

"In regular microteaching, what interested the students in the audience were the pedagogical strategies of the lecturing student. The subject of the lecture-they knew it. Here, what was interesting them was the topic of the lesson itself, because it was unknown. It was exciting. (Jasmine, C)

The "discovery" aspect of peer lecturing yielded specific "orientations toward science teaching" (Magnusson et al., 1999) in the preservice teachers. Although the academic requirements of the activity made most lectures structured according to a "didactic orientation", that is, focused on the transmission of scientific facts (Magnusson et al., 1999), the lectures were also the opportunity for the students to discover other orientations and specific motivations to learn and teach science (Seroussi \& Sharon, 2017). 6 students from all academic levels (Amal (B) and Jasmine (C) on the blowfish, Abigail (A) and Deborah (B) on the chameleon, Hannah (A) and Merav (A) on the peacock) expressed in the interview teaching goals corresponding to a the "conceptual change orientation" (Magnusson et al., 1999), that is the willingness to correct peers' misconceptions on the topic of their lecture, and two A students reported the willingness to introduce ecological values (protection of bees or avoidance of pointless destruction of ants) as a leading thread in their lecture.

\subsection{Regulative Gains in Teacher Training}

It seemed that the students used peer lecturing as a form of microteaching (Grossman, 2005) with academic instead of school-level topics. Indeed, they spontaneously included in their lessons strategies they had learned in the general pedagogical methods course, they made special efforts for classroom management when lecturing, and they assessed their own performance and that of their peers on the basis of pedagogical requirements. Yet, the pedagogical aspects of the lessons were not as developed in peer lecturing as in regular microteaching, due to our decision not to cross the boundaries of the zoology course and due to the limited time given to students' lectures. The purposely high scientific level and information concentration of the lectures, as well as their limited length, left less room in the lectures for demonstrating pedagogical skills. One of the students who turned out three years later as an outstandingly skilled teacher but a less enthusiastic science learner (Randi, 2004) expressed her appreciation in these terms:

"The lectures were too much like a marathon, we concentrated on delivering as much information as possible, and this was at the expense of pedagogy." (Merav, A)

In this framework, the students did not display much creativity about the technical format of their lesson: all lessons were teacher-centred (some called for active participation of the audience in the introduction), only one student (Elyiah, B) produced his presentation with software which was not the same as the one used by the professor, and only another one (Ofrah, B) presented a self-edited movie instead.

Similarly, our willingness to dedicate most of the time in the course to disciplinary learning did not leave much time in class for pedagogical feedback and reflection.

"In zoology, whenever there was something wrong with the pedagogy, they [the peers] didn't mention it because it was not so important." (Amal, B)

Yet all the students appreciated the opportunity given to them to apply to science teaching the skills learned in general teaching methods courses. Even the lowest achievers briefly described the strategies they included in their lesson,

"We took the learners into consideration. We asked them if they had questions, if they understood... we shared with them." (Amal, B),

while the most competitive students explained how they used their lecture as a deliberate display of teaching proficiency: 
"We took the knowledge from all the general teaching methods courses and we crammed it into our ten-minute lecture! For instance, if I say creative learning, we brought feathers, because it is really creative to bring something from the animal itself, new technologies, we brought the film..." (Merav, A).

The lecture was the place for the students to experiment with co-teaching formats. Cooperative teams were formed by half of the students, and these teams acted in different ways in front of the class. Some pairs spontaneously divided their lecture into two parts, each student teaching her part, but in other cases (Amal (B) and Jasmine (C), Abigail (A) and Deborah (B), Maria (B) and Amira (C)) each student introduced an alternating slide in the lecture, and this obliged both of them to be knowledgeable about the content of the entire presentation.

\subsection{Cognitive and Meta-Cognitive Gains in Teacher Training}

Concerning the link between PCK and SMK, peer lecturing seemed to display original advantages.

Peer lecturing seemed to influence students' beliefs about the level of SMK needed to teach a scientific topic. Indeed, all the students reported that in peer lecturing, compared to regular microteaching, the undiscussed proficiency of the professor and the literacy of the audience in the academic field of the lessons enhanced their awareness of the necessity for a high level of knowledge and enhanced the academic level of their lectures:

"In comparison to general microteaching, I have to come to the lecture twice as ready." (Bathsheba, A)

This situation also enhanced students' awareness of the necessity for a critical assessment of educational sources.

“... what they put on this internet site was wrong: a picture with the colours of the chameleon one on the top of the other - this is wrong! So if you explain it to the students using the picture, she [the professor] will lower your grade, because the picture is wrong, because she will know it's wrong." (Abigail, A)

Yet, some low-achieving students felt that along with the requirement for a high scientific level which it induced, the audience's literacy reduced its criticism about the formulation of basic knowledge:

"Here [contrary to microteaching sessions with non-science students], it is easy to manage the class and to explain, because they already have basic knowledge: if I get stuck with something, they will help me." (Morgane, C)

For two pairs of (A) students, peer lecturing was an opportunity to teach non-certain knowledge, that is, scientific phenomena lacking a single explanation:

"We simply introduced the three approaches and explained them. And we explained why we thought that one of the approaches was better.” (Merav, A)

In an attempt to assess the link between the lectures' scientific level and their impact on student's learning, we tried to relate students' answers on the final examination and the scientific level of the lectures. Yet there was no correlation between the grades given to the students' lecture, and the number of students who chose to answer the question related to this particular lecture in the final examination (Figure 1). For instance, the topic chosen by the majority of students in the examination (the blowfish - 11 times) was taught in the lecture which received one of the lowest grades, whereas some of the best lectures were not chosen at all in the examination. This reminds us that the factors which influence knowledge retention include not only the lecture's academic quality, but also many additional features, like the attractive nature of the topic, how easy it is to learn it, or the motivation originating from the strength of the social bond with the lecturing person. 


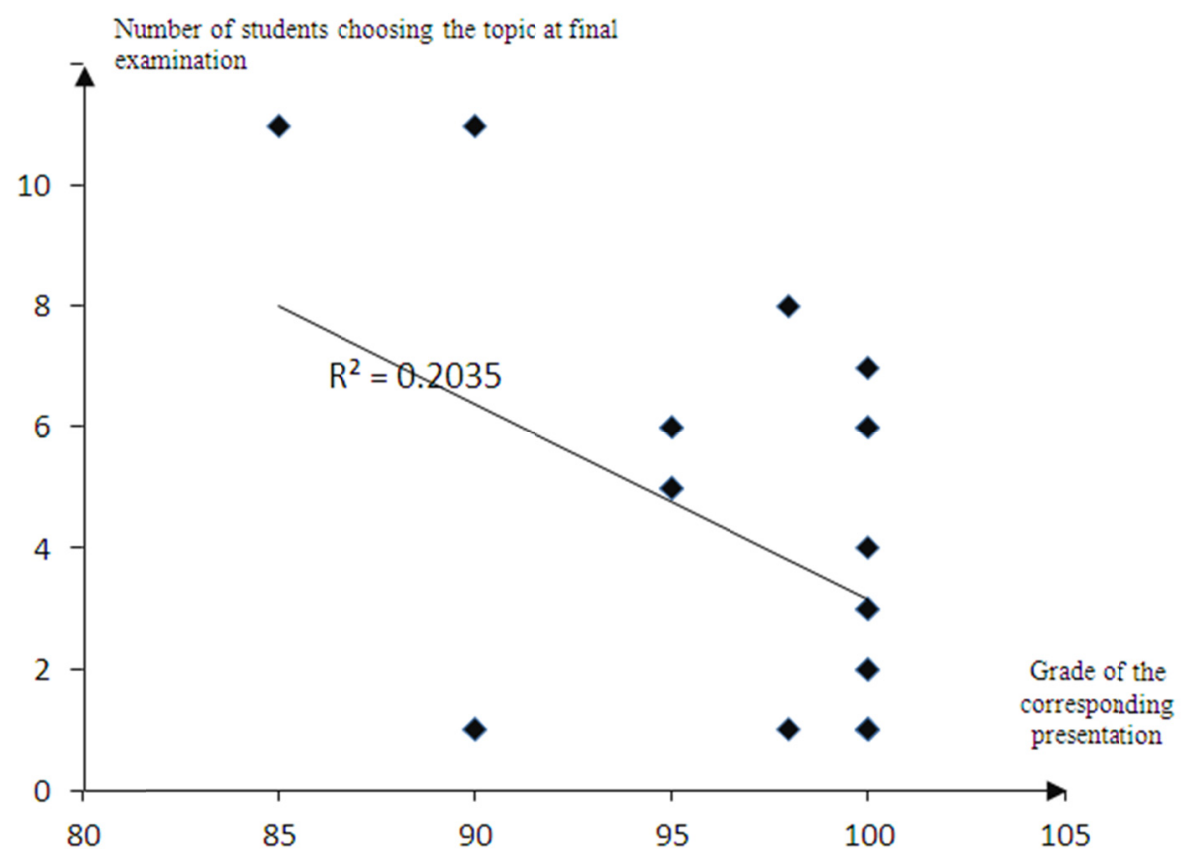

Figure 1. Number of students choosing to answer the essay question on a definite topic as a function of the scientific level of the presentation on this topic (as assessed by the grade received by the students who taught the topic in their presentation)

The preparation of the lectures appeared to be for all the students an opportunity to tackle "knowledge and beliefs about instructional strategies for teaching science" (Magnusson et al., 1999) and to develop a personal view in this field. In the interviews, the time devoted to reflection on teaching was as long as the time devoted to reflection on learning (Seroussi \& Sharon, 2017). On a formal basis, only a small number of students explicitly acknowledged peer lecturing as an opportunity to develop an original teaching style in science. Many students declared:

"I taught the way I thought was better",

but were unable to describe what was special in their teaching style. Some declared:

"I taught as I learned in methods courses" (Amal, B),

but their lessons were not always different from those of other students. Some explained why in their opinion, such an activity could not foster new ways of teaching (Feiman-Nemser \& Buchmann, 1985):

"I think that according to my level as a first-year student, I taught exactly like I am used to seeing people teach, the teachers who taught me, from the professors here. -Purposely or spontaneously? - Spontaneously, because I don't know anything else. As yet I don't know another way." (Naomi, A)

Yet, on a practical basis, it seems that the activity did induce an intensive reflection about ways of teaching, as can be seen, for instance, in the thorough justifications all students gave about the relative weights they gave to words and images in their presentations:

"See, I looked at a presentation, let's say like those of X and Y [professors in the college], and I understood that in science: say it less, show it more. But in practice, when you teach me new material, I do want to see it written. This is why I wrote down the main sentences in the presentation. -Contrary to what the lecturers do in the college? - Yes, they hardly write anything." (Abigail, A).

"When you use the white board, it is more efficient in giving a lesson, because it requires you to think more, to understand more, you are more active. But, you know, when everything is written in the presentation, it seems all right if you don't remember something. And this is definitely wrong." (Michal, B)

The "project-based learning" activity, which the students experienced as learners, was assessed by them as a teaching strategy. When asked, all the students declared that as teachers, they were willing to transfer the experiment to their pupils - although C students stated they would introduce simplifications in the activity. And 
indeed, in their field-application classrooms, the following year, most A students did actually organize small literature inquiry activities ending with pupils' presentation of their results to the class (this happened both in classes where the mentor teachers used literature inquiry themselves as a teaching tool, and also in classes where they did not). This observation suggests that most student teachers internalized the principles of peer lecturing enough to transfer their knowledge to the situations where they were the instructor.

"Knowledge and beliefs about students' understanding of specific science topics" (Magnusson et al., 1999) appeared to develop in peer lecturing, due both to the discovery component and to the peer teaching component of peer lecturing (Seroussi \& Sharon, 2017).

Many students explained how their ability to teach for conceptual change was supported by their acquaintance with their own difficulties when learning the topic they had to teach (discovery learning component) (Parker \& Heywood, 2011) and with their peers' difficulty in zoology in general (peer teaching component).

"I was sure that if I didn't know that, then most of the class didn't know. [...] We are all more or less at the same level, so I just looked at myself as a student, and so I could identify with them." (Naomi, A)

"Everybody was thinking like kids, like, the chameleon changes its colour according to what it is sitting on. I thought like that too. [...]. You have to search and to understand that, in fact, you also change your own conception." (Deborah, B)

Two students, Avigail (A) and Deborah (B) even developed a thoughtful theory of misconceptions corresponding to the newest insights in the field.

The acquaintance with peers' learning in zoology also helped some A students to address different types of learners in their lecture:

"Here, since I know the level of the class, like, I know the students personally, it becomes something else." (Rebecca, A)

But all $\mathrm{C}$ students explained that accounting for differences was too heavy a task for them, given their other difficulties, and B students reported they did not address students' differences by choice:

"You cannot adapt to everyone, because in the final analysis, the lecture is for the whole class." (Elijah, B)

Beyond the link between learning and teaching, which was induced de facto by the format of the activity-as revealed by the findings above-students' comments show that they themselves saw the processes of learning and teaching as intrinsically related. Their description of their work shows how they were involved in the co-construction of "knowledge for learning" and "subject-matter knowledge for teaching" (Shulman, 1986), with one activity sustaining the other: learning in order to understand sustained their ability to teach, and learning in order to teach sustained their understanding of the subject (see also Seroussi \& Sharon, 2017).

The link between learning and teaching also explicitly appeared on a reflective level, when the students expressed that they see self-concept as a learner and self-concept as a teacher as one single concept. On the one hand, self-concept as a learner was described as involving the transfer of information as a part of the mastery of the subject they learned:

"I really felt that I was a real science student. - Why? - Because I was researching by myself, I brought what looked right for me, I brought something that I understood, and I brought that to my friends. " (Tasnin, B)

On the other hand, self-concept as a teacher was described as including information searching and understanding:

"Yes, this experience involved us in the course, it helped us to understand, to search in academic papers, it helped. It's not just science that I have to know, I have to know beyond it, I am also a teacher, I am first and foremost a teacher, this is education to science. So it helped me a lot, to find new information, and not only the material that was supposed to be in the course." (Amal, B).

In addition to students' personal endeavour to prepare their lesson, the human environment in peer lecturing seemed to supply a lot of data to students' reflection about teaching. While only some students (overall 3 spontaneous reports) acknowledged that listening to the lectures of peers brought them insights under the form of positive or negative teaching examples, all the students expressed in the interviews a very intense analysis of their professor's pedagogical choices in building the activity. The activity's requirements were discussed very liberally and critically. On the one hand, the students acknowledged that the specific requirements of writing a summary and limiting the lecture to ten minutes helped them, from a pedagogical viewpoint, structure their 
lesson and focus on a limited topic. On the other hand, the requirement of publishing a summary before the lecture, or the use of peer assessment in the format adopted in the activity) raised contradicting opinions, which the students devoted a part of the interview to explaining:

"She [the professor] also asked us to send to the forum before the lesson a summary of what we were going to teach. I think it is inappropriate, because attention should be paid here to the surprise effect." (Abigail, A)

"But what she [the professor] did was good! The summary allows the teaching student to teach quicker. Instead of starting to explain what the core concepts are, the students in the audience already read, and they already had questions about what they wanted to know..." (Rachel, A).

In some cases, lack of agreement with the activity's requirement yielded an additional pedagogical effort, which included additional learning (see Seroussi \& Sharon, 2017).

The student teachers' better capacity to analyse the organization of the activity from their point of view as participants than to analyse their own learning in zoology, confirms the finding of Chamoso et al. (2012) about student teachers' reflection when learning subject matter knowledge in an academic course.

\section{Discussion}

The analysis of student teachers' reactions to peer lecturing supports our hypotheses about the benefits of peer lecturing in teacher training, but depending on the type of student concerned (A, B, or C).

The importance of disciplinary knowledge as a prerequisite to teaching was explicitly stressed by all the students participating to the activity. Peer lecturing had the advantage of giving students' lessons an assessor who was a specialist in the subject matter, and this seemed to generate a more ambitious atmosphere regarding the scientific level of the lessons' background and format. The question remains whether the students will stick to this attitude once they start teaching primary school.

Students' conception about the importance of PCK when teaching scientific contents was not explicitly stated (it seems logical that at this stage of their training, the students did not have the language to do that), but it was salient in students' descriptions and justifications of their teaching strategies. As shown, students' reports spontaneously expressed 3 out of 5 components of PCK in the model of Magnuson et al. (1999) - the two remaining components being irrelevant to the activity.

The awareness of the existence of prior conceptions in science was acknowledged by some students at different levels, but a thorough reflection about the right management of prior conceptions in teaching was proposed only by two high-achieving students. The following year, in order to improve this aspect of the activity, the first author added in a later run of peer lecturing the requirement to address in the lecture one misconception about the topic of the lecture, accompanied by explicit instruction on the subject of prior conceptions. Most students gave an appropriate treatment to the misconception they chose to include in their lesson. Two years later, in application school field-work, several A students spontaneously recalled the misconceptions part of the activity as a basis for a lesson in application school.

Students' formulation of the intrinsic proximity between the teaching and learning processes matches current conceptions about this matter (Baird, Fensham, Gunston, \& White, 1991; Vermunt \& Verloop, 1999). Indeed, because learning and teaching are based on similar cognitive steps, one of the processes automatically involves the other: deep learning implies knowledge organization and mastery, which is required for teaching, and concurrently, efficient teaching requires deep consciousness of the difficulties involved in learning the topic of the lesson.

Various forms of reflective and analytic thinking about learning and teaching were displayed by the students in their analysis of the activity. In our previous paper on peer lecturing (Seroussi \& Sharon, 2017, Table 2), we showed how the environment in this activity allowed the students to experience almost concurrently a variety of roles with respect to the teaching processes (learning in a regular lecture, learning by inquiry, teaching one's teammate, and, finally, teaching the class), and to adopt a variety of points of view in reflecting about teaching (as individual learners trying to self-regulate, as learners analysing professor's teaching practice, as teachers planning their own lesson, as participative observers in peers' lectures). The present report suggests that this multiplicity of situations helped the students to reflect about teaching as well, as it helped them to reflect about learning. Indeed, in general, reflection about teaching is based mainly on the comparison between the actual teaching situation and similar reference situations (Sparks-Langer \& Colton Bernstein, 1991). For instance, as reported earlier in this paper, when justifying the balance between words and images in her presentation, Abigail focused on her own needs as a learner and took both the position of the professor and that of the student, and 
Michal called upon her own needs as a teacher and compared her own teaching experience to the performance of a peer in teaching. In regular microteaching, the students have to recall the reference situations from their memories of past situations. In peer lecturing, the advantage is that the students experience not only the actions of preparing and giving a lesson, but also most of the reference situations (Parker \& Heywood, 2013). The situational proximity of the reference situations seems to improve their understanding (the difficulty to understand a lecture is felt more deeply when the student in difficulty is a friend rather than a distant memory). The temporal proximity of these situations seems to improve the retention of the reference experience and therefore the depth and accuracy of the analysis (it is easier to remember the details of a situation which has occurred in the recent past). Such a situation ensures more chances for reflection on teaching to be conducted, and with more depth.

Among the different analyses which the students conducted in the framework of peer lecturing, the critical assessment of the modalities of the activity itself and of the professor's behaviour as a coordinator in this activity should be especially noted. In peer lecturing, the habit of students to analyse their own teachers' intentions (Elen \& Lowyck, 1998) became a source of inspiration for them as future teachers. This is a possibility which is original to teacher training. Indeed, while there are other professions in which the professionals can check the relevancy of their knowledge on themselves (like psychologist or doctor), the teaching profession is the only profession whose object is a situation analogous to the training situation itself. In consequence, for teacher trainees, the training situation is like a picture including a mise en abyme of their personal situation as a teacher teaching her own audience, in a larger picture which shows the general training situation where the professor instructs all the teachers. This situation enables the students to analyse concurrently two teaching processes (own teaching and professor's teaching), under different points of view (learner and teacher), and to gain additional insights (Chamoso et al., 2012). Additionally, in our case, since in peer lecturing the teaching role of the students does not correspond to a very constructivist view of teaching (the lectures are even plain "transmission teaching"), the analysis of the professor's pedagogy was an opportunity for the students to relate to the issue of "teaching inquiry" and to prepare themselves to lead such activities with their pupils in the future.

\section{Conclusion}

In previous work (Seroussi \& Sharon, 2017), we showed how in peer lecturing, the addition of the peer teaching component to an inquiry activity, brings several original benefits regarding students' motivation and students' cognitive activity as learners, because the social context in which it occurs induced new motivational goals and an additional opportunity to construct knowledge. The current analysis shows that from the point of view of teacher training, the addition of a common learning situation and of disciplinary inquiry-learning in peer lecturing creates two valuable highlights for student teachers' behaviour and reflection: an emphasis on SMK, and the possibility of multiple perspectives for reflecting on learning and teaching. The field of teacher training is constantly searching for instructional frameworks encouraging preservice teachers' reflection about teaching (Richert, 1992). It seems that peer lecturing could be considered one of them.

Peer lecturing was used here as an introductory activity in science teaching for first-year student teachers. The activity was intended for students learning in a concurrent pattern (that is, receiving in parallel scientific and educational instruction), but it may be adapted to consecutive pattern curricula. In this activity, the interviews served as an opportunity for the students to express their conceptions and refine their thoughts in science teaching, but no institutional framework was attributed to the expression and the development of students' reflection about learning and teaching and to the ordered assimilation of the skills acquired in the activity in order to transfer them to other contexts. On the basis of the present results, we are now testing whether the addition of additional features to peer lecturing could turn it into a training tool dealing with different additional teacher education.

\section{References}

Baird, J. R., Fensham, P. J., Gunston, R. F., \& White, R. T. (1991). The importance of reflection in improving science teaching and learning. Journal of Research in Science Teaching, 28, 163-182. https://doi.org/10.1002/tea.3660280207

Ball, D. L., \& Cohen, D. K. (1999). Developing Practice, Developing Practitioners: Toward a Practice-Based Theory of Professional Education. In L. Darling-Hammond, \& G. Sykes (Eds.), Teaching as the Learning Profession: Handbook of Policy and Practice (pp. 3-32). San Francisco: Jossey-Bass.

Ball, D. L., Thames, M. H., \& Phelps, G. (2008). Content Knowledge for Teaching What Makes It Special? Journal of Teacher Education, 59(5), 389-407. https://doi.org/10.1177/0022487108324554 
Bandura, A. (1986). Social foundations of thought and action: A social cognitive theory. Englewood Cliffs, NJ: Prentice-Hall. https://doi.org/10.4135/9781446221129.n6

Briscoe, C., Peters, J. M., \& O’Brien, G. E. (1993). An Elementary Science Program Emphasizing Teacher's Pedagogical Content Knowledge within a Constructivist Epistemological Rubrique. In P. A. Rubba, L. M. Campbell, \& T. M. Dana (Eds.), Excellence in educating teachers of science, Yearbook of the Association for the Education of Teachers of Science (pp. 23-42). Columbus, OH: ERIC Clearinghouse for Science, Mathematics and Environmental Education.

Britner, S. L., \& Finson, K. D. (2005). Preservice Teachers' Reflections on Their Growth in an Inquiry-Oriented Science Pedagogy Course. Journal of Elementary Science Education, 17(1), 39-54. https://doi.org/10.1007/BF03174672

Capraro, R. M., Capraro, M. M., Parker, D., Kulm, G., \& Raulerson, T. (2005). The mathematics content knowledge role in developing preservice teachers' pedagogical content knowledge. Journal of Research in Childhood Education, 20(2), 102-118. https://doi.org/10.1080/02568540509594555

Chamoso, J. M., Cáceres, M. J., \& Azcárate, P. (2012). Reflection on the teaching-learning process in the initial training of teachers. Characterization of the issues on which pre-service Mathematics teachers reflect. Teaching and Teacher Education, 28, 154-164. https://doi.org/10.1016/j.tate.2011.08.003

Charmaz, K. (2006). Constructing grounded theory. A practical guide through qualitative analysis. London: Sage.

Corno, L., \& Randi, J. (1999). A design theory for classroom instruction in self-regulated learning? In C. M. Reigeluth (Ed.), Instructional design theories and models. New York: Erlbaum.

Crawford, B. A. (2007). Learning to teach science as inquiry in the rough and tumble of practice. Journal of Research in Science Teaching, 44(4), 613-642. https://doi.org/10.1002/tea.20157

Desimone, L. M. (2009). Improving Impact Studies of Teachers' Professional Development: Toward Better Conceptualizations and Measures. Educational Researcher, 38(3), 181-199. https://doi.org/10.3102/0013189X08331140

Elen, J., \& Lowyck, J. (1998). Students' views on the efficiency of instruction: An exploratory survey of the instructional metacognitive knowledge of university freshmen. Higher Education, 36(2), 231-252. https://doi.org/10.1023/A:1003227502618

Entwistle, N. (1991). Approaches to learning and perceptions of the learning environment. Higher Education, 22, 201-204. https://doi.org/10.1007/BF00132287

Evens, M., Elen, J., \& Depaepe, F. (2015). Developing Pedagogical Content Knowledge: Lessons Learned from Intervention Studies. Education Research International, Article ID 790417, 23 pages. https://doi.org/10.1155/2015/790417

Feiman-Nemser, S. (1983). Learning to teach. In L. Shulman \& G. Sykes (Eds.), Handbook of teaching and policy (pp. 150-170). New York: Longman.

Feiman-Nemser, S. (2001). From preparation to practice: Designing a continuum to strengthen and sustain teaching. Teachers College Record, 103, 1013-1055. https://doi.org/10.1111/0161-4681.00141

Feiman-Nemser, S., \& Buchmann, M. (1985). Pitfalls of experience in teacher preparation. Teachers College Record, 87, 49-65.

Friedrichsen, P., Munford, D., \& Zembal-Saul, C. (2003). Using inquiry empowering technologies to support prospective teachers' scientific inquiry \& science learning. Contemporary Issues in Technology and Teacher Education, 3(2), 223-239.

Friedrichsen, P. J., Abell, S. K., Pareja, E. M., Brown, P. L., Lankford, D. M., \& Volkmann, M. J. (2009). Does teaching experience matter? Examining biology teachers' prior knowledge for teaching in an alternative certification program. Journal of Research in Science Teaching, 46(4), 357-383. https://doi.org/10.1002/tea.20283

Grossman, P. (2005). Research on pedagogical approaches in teacher education. In M. Cochran-Smith, \& K. M. Zeichner (Eds.), Studying Teacher Education (pp. 425-276). Washington, DC: American Educational Research Association.

Hwang, Y., \& Vrongistinos, K. (2002). Elementary in-service teachers' self-regulated learning strategies related 
to their academic achievements. Journal of Instructional Psychology, 29(3), 147-154.

Justi, R., \& van Driel, J. (2005). A case study of the development of a beginning chemistry teacher's knowledge about models and modelling. Research in Science Education, 35(2-3), 197-219. https://doi.org/10.1007/s11165-004-7583-Z

Kind, V. (2009). Pedagogical content knowledge in science education: perspectives and potential for progress. Studies in Science Education, 45(2), 169-204. https://doi.org/10.1080/03057260903142285

Kramarski, B., \& Kohen, Z. (2015). Promoting the dual roles of teachers as self-regulated learners and self-regulated teachers. Paper presented at the AERA Conference, Chicago, USA.

Kramarski, B., \& Michalsky, T. (2009). Investigating preservice teachers' professional growth in self-regulated learning environments. Journal of Educational Psychology, 101(1), 161-175. https://doi.org/10.1037/a0013101

Lackner-Saylor, L., \& Johnson, C.C. (2014). The Role of Reflection in Elementary Mathematics and Science Teachers' Training and Development: A Meta-Synthesis. School Science and Mathematics, 114(1), 30-39. https://doi.org/10.1111/ssm.12049

Loughran, J., Mulhall, P., \& Berry, A. (2008). Exploring Pedagogical Content Knowledge in Science Teacher Education. International Journal of Science Education, 30(10), 1301-1320. https://doi.org/10.1080/09500690802187009

Luft, J. A., Firestone, J. B., Wong, S. S., Ortega, I., Adams, K., \& Bang, E. (2011). Beginning secondary science teacher induction: a two-year mixed methods study. Journal of Research in Science Teaching, 48(10), 1199-1224. https://doi.org/10.1002/tea.20444

Magee, P. A., \& Flessner, R. (2012). Collaborating to improve inquiry-based teaching in elementary science and mathematics method courses. Science Education International, 23(4), 353-365.

Magnusson, S., Krajcik, J., \& Borko, H. (1999). Nature, sources and development of pedagogical content knowledge for science teaching. In J. Gess-Newsome, \& N. G. Lederman (Eds.), Examining pedagogical content knowledge: The construct and its implications for science education (pp. 95-132). Dordrecht, The Netherlands: Kluwer Academic. https://doi.org/10.1007/0-306-47217-1

Mamlok-Naaman, R., Blonder, R., \& Hofstein, A. (2010). Providing chemistry teachers with opportunities to enhance their knowledge in contemporary scientific areas: a three-stage model. Chemistry Education Research and Practice, 11(4), 241-252. https://doi.org/10.1039/C0RP90005B

Mellado, V. (1998). Preservice Teachers' Classroom Practice and Their Conceptions of the Nature of Science. Science and Education, 6, 331-54. https://doi.org/10.1039/C0RP90005B

Michalsky, T. (2012). Shaping self-regulation in science teachers' professional growth: Inquiry skills. Science Education, 96(6), 1106-1133. https://doi.org/10.1002/sce.21029

Parker, J., \& Heywood, D. (2013). Exploring How Engaging With Reflection on Learning Generates Pedagogical Insight in Science Teacher Education. Science Education, 97(3), 410-441. https://doi.org/10.1002/sce.21049

Pintrich, P. R. (2004). A Conceptual Framework for Assessing Motivation and Self-Regulated Learning in College Students. Educational Psychology Review, 16(4), 385-407. https://doi.org/10.1007/s10648-004-0006-x

Poulson, L. (2001). Paradigm lost? Subject knowledge, primary teachers and education policy. British Journal of Education Studies, 49(1), 40-55. https://doi.org/10.1111/1467-8527.t01-1-00162

Randi, J. (2004). Teachers as self-regulated learners. Teachers College Record, 106(9), 1825-1853. https://doi.org/10.1111/j.1467-9620.2004.00407.x

Richert, A. E. (1992). The Content of Preservice Teachers' Reflections within Different Structures for Facilitating the Reflective Process. In T. Russel \& H. Munby (Eds.), Teachers and Teaching: From Classroom to Reflection. London: the Falmer Press.

Rubba, P. A, Campbell, L. M., \& Dana, T. M. (Eds.) (1993). Excellence in educating teachers of science. Yearbook of the Association for the Education of Teachers of Science, Columbus, OH, ERIC Clearinghouse for Science, Mathematics and Environmental Education, 23-42.

Schön, D. A. (1987). Educating the Reflective Practitioner. San Francisco: Josey-Bass 
Seroussi, D. E., \& Sharon, R. (2017). Peer Lecturing as Project-Based Learning: Blending Socio-Affective Influences with Self-Regulated Learning. International Education Studies, 10(1). https://doi.org/10.5539/ies.v10n1p109

Shulman, L. S. (1986). Those Who Understand: Knowledge Growth in Teaching. Educational Researcher, 15(2), 4-14. https://doi.org/10.3102/0013189X015002004

Shulman, L. S. (1987). Knowledge and teaching: foundations of the new reform. Harvard Educational Review, 57(1), 1-23. https://doi.org/10.17763/haer.57.1.j463w79r56455411

Sparks-Langer, G. M., \& Colton-Bernstein, A. (1991). Synthesis of Research on Teachers' Reflective Thinking. Educational Leadership, 48(6), 37-44.

Sperandeo-Mineo, R. M., Fazio, C., \& Tarantino, G. (2006). Pedagogical content knowledge development and pre-service physics teacher education: a case study. Research in Science Education, 36(3), 235-268. https://doi.org/10.1007/s11165-005-9004-3

Vermunt, J. D., \& Verloop, N. (1999). Congruence and friction between learning and teaching. Learning and Instruction, 9, 257-280. https://doi.org/10.1016/S0959-4752(98)00028-0

Wilson, S. M., Shulman, L. S., \& Richert, E. R. (1988). '150 different ways' of knowing: Representations of knowledge in teaching. In J. Calderhead (Ed.), Exploring Teachers' Thinking. New York: Taylor and Francis.

Zeichner, K. (1996). Teachers as reflective practitioners and the democratization of school reform. In K. Zeichner, S. Melnick, \& M. L. Gomez (Eds.), Currents of reform in pre-service teacher education (p. 199-214). New York: Teachers College Press.

Zimmerman, B. (2008). Investigating Self-Regulation and Motivation: Historical Background, Methodological Developments, and Future. American Educational Research Journal, 45, 166-183. https://doi.org/10.3102/0002831207312909

\section{Copyrights}

Copyright for this article is retained by the author(s), with first publication rights granted to the journal.

This is an open-access article distributed under the terms and conditions of the Creative Commons Attribution license (http://creativecommons.org/licenses/by/4.0/). 